\title{
Shareholder Response to Research \& Development Expenditure: A Study of Pharmaceutical Industry
}



Volume 11, Number 1

January 2017, pp. 35-48

\author{
Deepak Danak \\ Punita Rajpurohit
}

Institute of Management, Nirma University

(danak@nirmauni.ac.in)

(punitarajpurohit@nirmauni.ac.in)

\begin{abstract}
What do the shareholders value more: the current profit or the future profit? We have tried to look into this classic issue in corporate finance in the context of pharmaceutical industry in India. If current profit prevails over the future profit, it would lead to profit maximizing behavior on the part of finance managers; if it is the other way round, it would lead to value maximizing behavior. Theory of financial economics accords value maximization as the right goal; however, the shareholder reaction may or may not be supporting it. Since the $R \& D$ expenditure reduces current profit, but has a potential for enhancing future profit, this study tries to measure its impact on shareholder value creation. The results indicate that companies engaging in $R \& D$ activity command higher valuations in terms of $M V / B V$ ratio. The regression results indicate that $M V / B V$ ratio is explained by Return on Equity (ROE) and $R \& D$ expenditure, with $R \& D$ expenditure having more weightage.
\end{abstract}

Keywords: Du Pont Analysis, Pharmaceutical Industry, Price to Book Ratio, MV/BV Ratio, R\&D Intensity, Shareholder Value Creation

\section{Introduction}

The modern theory of financial economics accords value maximization as the right goal of a company. Value is the present value of future returns discounted for their inherent risk. Thus, value is a positive function of future returns, and inverse function of risk of returns. Contrasted to this is the traditional approach which conceptualizes the value as a function of only the current returns. In that case, the risk becomes irrelevant. It has been widely observed that developed economies uphold value maximization goal; whereas profit maximization orientation happens to be evident in many developing economies. It is in this context that this paper tries to develop an insight into what Indian investors hail more: the current profit or the future profit?

$\mathrm{R} \& \mathrm{D}$ expenditure is a unique item which reduces the current profit, but creates a promise for much higher future profits. As per AS 26 (which was applicable during the period of this study), companies can write off practically the entire $R \& D$ expenditure in the year of its incurrence. Our interactions with some of the CFOs also substantiate the same feeling. Even the income tax rules also do not come in the way. As a result, the reported current profit reduces in favor of potentially much higher future profits. This dichotomy makes $R \& D$ expenditure an excellent identifier 
of the shareholder preference for current vs. future profit. Here, it should be noted that the R\&D expenditure expressed as an absolute amount cannot offer a proper comparison, so it has to be used as a relative measure. Accordingly, R\&D expenditure divided by sales is a commonly used measure, which is often referred to as 'R\&D Intensity'. We also use this measure.

As far as the shareholder value measurement is concerned, there are two popular metrics, viz., the Market Value to Book Value ratio (MV/BV ratio), and Price/Earnings ratio (P/E ratio). Since both the metrics have the same numerator in terms of value (i.e. price) of equity, the difference between the two lies in their denominators. Earnings are more susceptible to short-term economic fluctuations as well to accounting policies. Book value is largely free from those limitations. Further, since book value stands for the capital contributed by the investors to the company, its comparison to the market value denotes the value created by the company for the equity investors. So, MV/BV ratio emerges as a more acceptable metric of shareholder value creation. According to Lev and Sougiannis (1999), the economic theory postulates that the difference between market and book values of companies reflects their future abnormal profits. Further, as Branch and Gale (1983) note, the book values usually provide an acceptable measure of available corporate resources. Moreover, book values are readily available and relatively stable over time. They write, "The ratio of stock price to per-share book value $(\mathrm{P} / \mathrm{B})$ should be used as a measure of relative stock prices. The extent to which $\mathrm{P}$ exceeds $\mathrm{B}$ reflects the going-concern value which effective management adds to the resources under its control. A ' $\mathrm{P}$ ' that is less than ' $\mathrm{B}$ ' suggests that management is imparting negative value to the firm's resources." Chen, Chang and Hwang (2005) also have used market to book value ratio as dependent variable in their regression model with $R \& D$ expenditure and advertising expenditure as proxy for innovative and relational capital.

So, in order to understand the preference of typical Indian investors on the issue of current profit vs. future profit, we examine the influence of ROE (as a measure of current profit) and $R \& D$ Intensity (as a proxy of future profit) on the MV/BV ratio.

\section{Literature Review}

There have been many studies, particularly in west, that examine the relationship between the R\&D Intensity and MV/BV ratio. Some of them take the route of event studies using the R\&D investments announcements, whereas some others undertake to use the R\&D Intensity as possible explanation for the higher MV/BV ratios.

As far as the event studies are concerned, the following studies are noteworthy. Chan, Martin and Kensinger (1990) examined share-price responses to 95 announcements of increased R\&D spending. By performing cross-sectional analysis, they found that high-technology firms that announce increases in R\&D spending have positive abnormal returns on average, whereas it is opposite in case of lowtechnology firms. Doukas and Switzer (1992) investigated the stock market's valuation of the R\&D expenditure plans of U.S. firms. They proposed a model that relates expenditures on innovative activity to the market value of the firm. The study used a sample of announcements that were made by firms that accounted for over $58 \%$ of company-funded R\&D in the United States in 1984. The results were consistent with the postulations of the model. It revealed significant differences in the abnormal returns for firms operating in different marketing environments. 
Especially, for firms in industries characterized by high (low) seller concentration, announcements of increases in planned $R \& D$ expenditures were associated with significant positive (negative) excess stock returns. According to them it is consistent with Schumpeterian view on the relationship between market structure and innovation that predicts a differential market response to $R \& D$ which depends on the firm's market concentration. They found that the market responded favorably to larger $R \& D$ spending increases, where the rate of return to investment in $R \& D$ was quite high. Szewczyk, Tsetsekos and Zantout (1996) examined the role of investment opportunities and free cash flow in explaining R\&D-induced abnormal returns. After controlling for firm size, financial leverage, dividend yield, ownership structure, and industry structure, they found a significant positive relation between a firm's Tobin's $\mathrm{q}$ and its stock price reaction to announcements of increases in $R \& D$ expenditures. Finally, they found that R\&D induced abnormal returns are also positively related to the percentage increase in $R \& D$ spending, the firm's debt ratio, and institutional ownership. Lev and Sougiannis (1999), in their study, captured the abnormal profits for a large sample of technology-based companies by estimating the value of the offbalance sheet investment value of R\&D capital. Their results showed that: (i) $R \& D$ intensive firms command higher valuations; (ii) R\&D capital is associated with their subsequent stock returns; and (iii) The association between R\&D and subsequent returns appears to result from an extra-market risk factor inherent in $R \& D$, rather than from stock mispricing. In conclusion, the event study based researches establish that the stock market reacts favourably to $R \& D$ investment announcements. However, such reactions are futuristic in nature, so they may or may not continue to sustain over a longer period of time. Thus, it makes a case for taking a historical analysis route to see whether the R\&D investment actually resulted into shareholder value creation in future period or not. Some prominent studies on this lines are compiled below.

Branch and Gale (1983) proposed a model of stock price performance. According to them, the factors that determine stock price are return on equity, investment growth, R\&D Intensity, payout and interest coverage. The factor of investment growth and R\&D Intensity reflect growth expectations of investors. They argued that profitability drives stock prices; however, investors are particularly interested in future profitability. Jaffe (1986) modeled the market value of the firm relative to the current R\&D Intensity. The regression results of study indicate that investors place three times higher value on the R\&D capital as contrasted to other capital.

Cockburn and Griliches (1987) examined the impact of R\&D on the firm's value using Tobin's q. They suggested that the market's relative valuation of the firm is a function of the firm's intangible capital stocks made up of R\&D and patents besides tangible capital stocks. Their results indicate that the market's valuation of the firm's R\&D investment is substantial. Sougiannis (1994) used cross-sectional data to estimate a recursive system of two equations: one for earnings, and another for valuation. The valuation equation relates market values of equity to book values, earnings, and $\mathrm{R} \& \mathrm{D}$ expenditures. It determines how the accounting and $\mathrm{R} \& \mathrm{D}$ numbers are valued in the market. The results from their valuation model indicate that investors place a high value on $R \& D$ investments. On average, a one-dollar increase in $\mathrm{R} \& \mathrm{D}$ expenditure produces a five-dollar increase in market value. Chan, Lakonishok and Sougiannis (2001) examined whether stock prices fully value firm's intangible assets, especially research and development expenditure. They found that 
the average historical stock returns of all the firms doing R\&D matches the returns of firms without R\&D. Further, R\&D Intensity is positively associated with return volatility. However, the market is too pessimistic about beaten-down R\&D-intensive technology stocks' prospects. Thus, companies with high R\&D to equity market value earn large excess returns. Ehie and Olibe (2010) examined the association between investment in R\&D and market value among US manufacturing and service industries over an 18-year period covering 26,500 firm-years. The study also investigated the impact of a major economic disruption - the terrorist bombing of the World Trade Center in New York on September 11, 2001 (9/11) - on R\&D investment relative to the performance of a firm. After controlling for firm size, industry concentration, and leverage, they found that $R \& D$ investment positively affects firm performance. However, they found that, in manufacturing sector, its effect was more positive than the service sector during pre-9/11, but the situation turned upside down post-9/11. Sonenshine (2010) examined the relationship between R\&D Intensity and MV/BV ratio in the context of size of the firm. They argued that larger firms have innovation advantages over small firms due to economies of scale and scope in research, financing advantage and knowledge complementarities. In conclusion, all these historical analysis-based studies clearly establish the significance of R\&D expenditure on creating shareholder value. Probably as a result, what we find is that the recent studies conducted in last five years go a step forward to bring in other related dimensions, too. For example, Lee \& Choi (2015) analyzed the time lag effect of R\&D investment in Korean pharmaceutical companies for a period of 2000 to 2012 with the objective to study the impact of R\&D investment on enterprise value. They found positive impact of R\&D intensity on Tobin's q. However, R\&D intensity for year $\mathrm{t}-2$ and $\mathrm{t}-5$ were statistically significant. $\mathrm{R} \& \mathrm{D}$ intensity for the years $\mathrm{t}-1, \mathrm{t}-3$ and $\mathrm{t}-5$ were not found to be statistically significant. Chen, Chan, Hung, Hsiang \& Wu (2016) compared the impact of R\&D expenditures and marketing expenditures on corporate performance. The industry characteristics and investment densities were used as the moderating factors. They found that both R\&D and marketing expenditures had positive impact on operating performance. However, R\&D expenditures had longer deferred effect than marketing expenditure. Further, they found that the $R \& D$ effect was more prominent in case of manufacturing firms as contrasted to service firms. Gu (2016) used real option model to study joint effect of $R \& D$ investment and product market competition on stock returns. Monthly portfolio abnormal returns were computed by running time series regression of portfolio excess returns using various multi-factor asset pricing models. He found that R\&D intensive firms do earn a higher return. However, particularly, in case of competitive industries, the $R \& D$ initiative of one firm gets replicated by other competitors resulting into enhancement of their systematic risk. Nonetheless, even after accounting for this enhanced risk, the returns were abnormally high. Lome, Heggeseth \& Moen (2016) studied the effect of R\&D Intensity on corporate performance during financial crisis. Using a sample of 247 Norwegian manufacturers and applying binary logistic regression, they found that firms who spent considerably on $R \& D$ activities performed better than other firms during the late 2000s financial crisis. They also analyzed the time lag between R\&D investment and its effect on revenue, and found a lag of two years, with an even stronger effect after three years. 
To summarize, R\&D Intensity clearly emerges as positively related to MV/BV ratio. However, at the same time, there are moderating factors like firm size, market structure, leverage, etc.

\section{Research Gap and Research Problem}

In India, in our knowledge, there has not been any notable research, even in terms of examining the basic relationship that market valuation of equity could be a direct function of R\&D investments. Further, there is no study that models shareholder value as a function of current profitability as well a promise of long-term growth embedded in its current expenditure on R\&D.

Given this research gap, we frame our research problem as: What do the shareholders value more: the current profit or the future profit? We have tried to look into this classic issue in corporate finance in the context of pharmaceutical industry in India, since it is characterized by good amount of R\&D expenditure. If current profit prevails over the future profit, it would lead to profit maximizing behavior on the part of finance managers; if it is the other way round, it would lead to value maximizing behavior. Theory of financial economics accords value maximization as the right goal; however, the shareholder reaction may or may not be supporting it. So, this study uses MV/BV ratio as a measure of value creation, and attempts to examine the impact of R\&D investments as a proxy for future profit, and Return on Equity (ROE) as a measure of current profitability on MV/BV Ratio.

\subsection{The Sample}

\section{Research Design}

We have chosen pharmaceutical industry of India as R\&D is quite evident in it. The data is sourced from AceEquity Database. It contained 229 listed companies in the pharmaceutical sub-industry category. Out of them, there were a lot of data gaps in case of 77 companies. For the remaining 152 companies the data were available for most of the years. However, we decided to select only those companies for which the data would be available for all the years to avoid any approximations due to missing data. Accordingly, only 73 companies met our requirements in terms of availability of complete data regarding various metrics as well as research and development expenditure information for the entire period of study. Thus, finally, our sample consists of 73 companies that include both: the experiment group, and the control group.

\subsection{Time Frame \& Data Collection}

As shown above, the study is based on secondary data that have been sourced from AceEquity database. Since the database captures the data from published financial statements of the companies, and at the same time does not regroup the data, there is no fear of any distortions in the data. Time frame of the study is 10 years period from 2005-06 to 2014-15. This makes it an optimum period that is not too large or too small. In view of the dynamic nature of the industry structures, it is not too large, but at the same time, it is fairly large enough to capture the pre-recession as well as the revival period.

\subsection{Data Analysis Method}

First, we categorize all the 73 pharmaceutical companies into three classes: (i) those indulging into $\mathrm{R} \& \mathrm{D}$ and having $\mathrm{MV} / \mathrm{BV}$ ratio greater than 1, (ii) those indulging into 
$\mathrm{R} \& \mathrm{D}$ and having $\mathrm{MV} / \mathrm{BV}$ ratio equal to or less than 1, and (iii) those not indulging into $\mathrm{R} \& \mathrm{D}$. We conduct ANOVA and t-Test for examining whether there are significant differences among these three classes on the parameters of interest. Then, in order to measure the impact of research and development expenditure on value creation for shareholders, we conduct regression analysis for both the groups of companies, viz., having $\mathrm{MV} / \mathrm{BV}>1$, and $\mathrm{MV} / \mathrm{BV}<1$. Since the second group has only three observations, conducting multiple regression would not make a sense, so we opt for running simple regression equation for both the groups. The regression model has MV/BV ratio as dependent variable and Return on Equity (ROE) which is a measure of current profitability, and $R \& D$ Intensity which is a measure of a promise of long-term growth as independent variables.

\subsection{Market Value to Book Value Ratio}

This is an adapted form of Tobin's q. It is worked out as market value of the company's equity divided by book value of the net worth of equity investors. It is a measure of 'value created'. Economically, if market assigns higher value to a company's equity than the net worth as shown in the books of accounts (which is equal to the money invested by equity subscribers in terms of paying for acquiring share and subsequently plowing back of profits), it can be inferred that the enterprise has created value for its investors. Value creation being the prime goal of any enterprise, higher the ratio (over unity value), better it is. Branch and Gale (1983), Sougiannis (1994) and Chen, Chang and Hwang (2005) also used it as a measure of value creation.

\subsection{Return on Equity}

It is measured as net profit divided by total equity invested measured as net worth. It is expressed as percentage, which shows net profit generated for every 100 rupees invested by equity holders in terms of paying for acquiring share and subsequently plowing back of profits.

\subsection{Research \& Development Intensity}

R\&D Intensity is a key metric reflecting the quality leadership of the firm. It is the ratio of firm's $R \& D$ investment to its sales revenue, which shows the percentage of sales revenue that is reinvested in R\&D. Branch and Gale (1983), Martin and Kensinger (1990), Chan, Lakonishok and Sougiannis (2001), Chao and Kavadias (2009), Sonenshine (2010), etc. also used it in their studies.

The companies are divided into three sets. First set consists of 31 the companies engaged in $R \& D$ and having $M V / B V$ ratio greater than 1 . These are the value creating companies. The second set consists of 3 companies engaged in R\&D and having $\mathrm{MV} / \mathrm{BV}$ ratio less than 1 . These are the companies that have failed to create value for its shareholders in spite of expending on $R \& D$. The third set consists of the 39 companies that are not engaged in $R \& D$.

\section{Hypotheses}

Our research problem requires us to model the MV/BV ratio as a function of ROE and R\&D Intensity. Towards that, we use Du Pont identity which postulates that $\mathrm{ROE}=\mathrm{ROA} X$ Equity Multiplier (i.e. financial leverage); where ROA = Earnings Before Interest and Tax Margin (EBIT Margin) X Asset Turnover Ratio (ATOR). 
Since R\&D Intensity is imbibed in the ROA, the Du Pont framework is used to form the following set of null hypotheses in order to conduct the desired inquiry.

$\mathrm{HO}_{1}$ : There is no significant difference between the companies engaging into R\&D and not engaging into $\mathrm{R} \& \mathrm{D}$ on the count of $\mathrm{MV} / \mathrm{BV}$ ratio.

$\mathrm{HO}_{2}$ : There is no significant difference among the three classes of companies (i.e. engaging in $R \& D$ and having $M V / B V<1$, engaging in $R \& D$ and having $M V / B V>1$, not engaging in $R \& D$ ) on the count of $M V / B V$ ratio.

$\mathrm{HO}_{3}$ : There is no significant difference among the three classes on the count of their ROE.

$\mathbf{H O}_{4}$ : There is no significant difference among the three classes on the count of their ROA.

Ho $_{5}$ : There is no significant difference among the three classes on the count of EBIT Margin.

H0$_{6}$ : There is no significant difference in the R\&D Intensity between the two groups of companies engaging into R\&D (in terms of their MV/BV ratios being more than one or otherwise).

$\mathrm{HO}_{7}$ : MV/BV ratios are not explained by R\&D Intensity and ROE.

The first two hypotheses would provide the basis for further inquiry. If significant difference is found among the firms on the count of MV/BV ratios, then hypotheses 3 to 6 would provide the rationale for the hypothesis 7 . Our alternate hypotheses are directional in nature, suggesting better performance of the firms engaged in R\&D. Accordingly, in case of $\mathrm{t}$-Test, the statistics are calculated for one-tail to examine whether the R\&D firms do better.

\section{Analysis, Findings and Discussion}

As discussed earlier, since our focus is on examining differences among the three groups of companies [namely (i) those indulging into R\&D and having MV/BV ratio greater than 1, (ii) those indulging into $R \& D$ and having $M V / B V$ ratio equal to or less than 1, and (iii) those not indulging into $R \& D$ ], the analysis is conducted on the cross-sectional data. The average score of a company over the period of study for the given variable is considered. The resultant descriptive statistics are presented in Table 1.

Table 1 Summary Measures

\begin{tabular}{|c|c|c|c|c|c|c|c|c|c|}
\hline \multirow{3}{*}{$\begin{array}{c}\text { Groups } \\
\text { Variables } \\
\end{array}$} & \multicolumn{6}{|c|}{ Firms Engaged in R\&D } & \multirow{2}{*}{\multicolumn{3}{|c|}{$\begin{array}{c}\text { Firms Not Engaged in } \\
\text { R\&D } \\
\text { (39 Companies) }\end{array}$}} \\
\hline & \multicolumn{3}{|c|}{$\begin{array}{c}\text { MV/BV }<1 \\
\text { (31 Companies) }\end{array}$} & \multicolumn{3}{|c|}{$\begin{array}{c}\text { MV/BV>1 } \\
\text { (3 Companies) }\end{array}$} & & & \\
\hline & Mean & Median & SD & ean & Median & SD & Mean & Median & SD \\
\hline Sales (Crore & 3 & 235.55 & 3 & 1 , & 7 & $1 \mathrm{c}$ & 11 & 32.60 & o \\
\hline $\begin{array}{l}\text { R\&D Intensity } \\
(\%)\end{array}$ & 2.3496 & 2.7563 & 1.0696 & 6.0351 & & 4.2. & NA & $\mathrm{N}$ & $\mathrm{N}$ \\
\hline EBITM $(\%)$ & (2) & .387 & 4.1965 & & & & & & \\
\hline ROA & 3.5635 & 4.4755 & 2.4130 & 10.691 & 10.481 & 5.2547 & 3.4764 & 02 & 6.1609 \\
\hline ROE (\%) & .3288 & 10.721 & 6.7928 & 19.488 & 20.494 & 8.7236 & 8.3550 & 9.1818 & 12.875 \\
\hline MV/BV Ratio & 0.8704 & 0.8887 & 0.0792 & 3.5040 & 2.9273 & 1.7103 & 1.2928 & 0.8938 & 1.0433 \\
\hline
\end{tabular}


Hypothesis- 1 is examined by conducting t-Test on MV/BV ratio for the two groups of companies viz., indulging into $\mathrm{R} \& \mathrm{D}$, and not indulging into $\mathrm{R} \& \mathrm{D}$. The results are compiled in Table 2.

Table 2 t-Test for MV/BV Ratio: Two Sample Assuming Unequal Variances

\begin{tabular}{|l|c|c|}
\hline & R\&D Companies & Non R\&D Companies \\
\hline Observations & 34 & 39 \\
\hline Mean & 3.35 & 1.29 \\
\hline Variance & 3.36 & 1.09 \\
\hline T-Value & \multicolumn{2}{|c|}{5.85} \\
\hline T- Critical Value (One Tail) & \multicolumn{2}{|c|}{1.67} \\
\hline P-Value (One Tail) & \multicolumn{2}{|c|}{0.000} \\
\hline
\end{tabular}

For greater accuracy of results, the t-Test is conducted on the assumption that the variances in the two groups are unequal. The results unequivocally show that the shareholders attach much higher value to those companies that engage into R\&D. Of course, the accompanying variance is also equally higher, which may be taken as reflecting the inherent risk of failure of $R \& D$ initiatives. However, even with that higher variance, the one-tail t statistic is highly significant suggesting that the $R \& D$ firms finds a great favour with investors as compared to the non-R\&D firm. Thus, there is a prima-facie case for investigating the matter, further.

Since out of $34 \mathrm{R} \& \mathrm{D}$ companies 3 companies turn out to be value destroyers as revealed by their $\mathrm{MV} / \mathrm{BV}$ ratio values of less unity, now we divide the R\&D companies into two sub groups, resulting into a total of three groups to get a better insight. Accordingly, Hypothesis- 2 is examined by conducting ANOVA on MV/BV ratios of those three groups of companies. The results are compiled in Table 3.

Table 3 ANOVA Results for MV/BV Ratio Differences

\begin{tabular}{|l|c|c|c|c|c|}
\hline \multicolumn{1}{|c|}{ Groups } & Count & Average & F & P-value & F critical \\
\hline Non R\&D & 39 & 1.29 & 24.42 & 0.000 & 3.13 \\
\hline R\&D: MV/BV > 1 & 31 & 3.50 & & & \\
\hline R\&D: MV/BV < 1 & 3 & 0.87 & & & \\
\hline
\end{tabular}

It can be seen that there is a significant difference among the three classes of companies on the count of their MV/BV ratios. Thus, Hypothesis-2 gets rejected, which, now, provides the basis for conducting further inquiry into the explanations for the differences. However, before we go into it, it would be apt to dwell here for a while to seek some explanation for a little higher value of $\mathrm{MV} / \mathrm{BV}$ ratio for companies not engaging into $R \& D$ over their counterparts engaging into $R \& D$ but not creating value. It intuitively appears that there may be some threshold level of R\&D expenditure, below which it may prove to be only a wasteful exercise. In that case, lesser than a threshold level R\&D expenditure does not increase the MV/BV ratio. Hypothesis - 6 can throw some light on this intuitive assumption. 
Since the differences in MV/BV ratios can be due to differences in current shareholder profit measured as ROE, Hypothesis-3 is examined by conducting ANOVA on ROE. The results are compiled in Table 4.

Table 4 ANOVA Results for ROE Differences

\begin{tabular}{|l|c|c|c|c|c|}
\hline \multicolumn{1}{|c|}{ Groups } & Count & Average & F & P-value & F Critical \\
\hline Non R\&D & 39 & 8.36 & 8.92 & 0.000 & 3.13 \\
\hline R\&D: MV/BV > 1 & 31 & 19.49 & & & \\
\hline R\&D: MV/BV < 1 & 3 & 8.33 & & & \\
\hline
\end{tabular}

It can be seen that there is significant difference among the three classes of companies on the count of their ROE ratios. Thus, Hypotesis- 3 gets rejected, which, now, provides the basis for using ROE ratios as an explanatory variable for explaining the differences in MV/BV ratios. Here, it would be interesting to examine the reasons for the differences in average value of ROE. The average ROE for first group (i.e. Non R\&D companies) is slightly higher than the third group (i.e. MV/BV $<1$ ), which is obviously due to the fact that the R\&D expenses being written off in the same year, the first group shows lower profitability (i.e. ROE) in comparison to the third group. Further, when the two groups of more than unity and less than unity values of $\mathrm{MV} / \mathrm{BV}$ ratio are compared, it also leads to a hypothesis that the difference in $\mathrm{MV} / \mathrm{BV}$ ratios may be due to the differences in their ROE ratios. As such, the incidence of $\mathrm{R} \& \mathrm{D}$ expenditure can have two opposite effects on the ROE. One unfavorable effect is in terms of lowering the profits since most of the companies write it off in the same year of its incurrence. The favorable effect stems from differentiation resulting into brand value that allows the firm to charge premium price which seems to be more powerful. However, if it is so, then there must also be a significant difference in ROA among those three groups of firms as the ROE is likely to be distorted due to financial leverage since the ROE is a product of ROA and Equity Multiplier as per the Du Pont identity. So, if, the difference in ROA turns out significant, then only we can relate the differences in $\mathrm{MV} / \mathrm{BV}$ to the differences in ROE.

Hypothesis-4 is examined by conducting ANOVA on ROA. The results are compiled in Table 5.

Table 5 ANOVA Results for ROA Differences

\begin{tabular}{|l|c|c|c|c|c|}
\hline \multicolumn{1}{|c|}{ Groups } & Count & Average & F & P-value & F critical \\
\hline Non R\&D & 39 & 3.48 & 14.21 & 0.000 & 3.13 \\
\hline MV/BV > 1 & 31 & 10.69 & & & \\
\hline MV/BV < 1 & 3 & 3.56 & & & \\
\hline
\end{tabular}

Table-5 unequivocally casts its vote in favor of R\&D engaging companies commanding higher price for their products. At the same time, it provides an explanation for an unresolved issue left earlier that companies not engaging into $R \& D$ have a little higher value of ROE over their counterparts engaging into R\&D. It becomes very clear that this anomaly has nothing to do with EBIT Margin; rather, it must be due to higher Equity Multiplier. 
Since the impact of premium price can be best captured in EBIT Margin, Hypothesis-5 is formed towards that. It is examined by conducting ANOVA on EBIT Margin. The results are compiled in Table 6.

Table 6 ANOVA Results for EBIT Margin Differences

\begin{tabular}{|l|c|c|c|c|c|}
\hline \multicolumn{1}{|c|}{ Groups } & Count & Average & F & P-value & F critical \\
\hline Non R\&D & 39 & 6.67 & 3.34 & 0.041 & 3.13 \\
\hline $\mathrm{MV} / \mathrm{BV}>1$ & 31 & 24.09 & & & \\
\hline $\mathrm{MV} / \mathrm{BV}<1$ & 3 & 6.67 & & & \\
\hline
\end{tabular}

It can be seen that there is significant difference among the three classes of companies on the count of their EBIT Margins. Thus, Hypotesis-5 gets rejected, which, now, provides the basis for using EBIT Margins as an explanatory variable for explaining the differences in MV/BV ratios. Average EBIT Margin of value generating firms is drastically more than that of other two groups. This observation confirms the view that companies engaging into $R \& D$ command premium price for their products. However, practically the same value for average EBIT Margin for the other two groups remain a grey area, which is further probed with the help of Hypothesis-6, which examines whether the R\&D expenditure (measured here as R\&D Intensity) could be a differentiating factor between the firms with MV/BV ratio greater than one, and $\mathrm{MV} / \mathrm{BV}$ ratio less than one.

Table 7 compiles the results for t-Test conducted for Hypothesis-6.

Table 7 t Test for $R \& D$ Intensity: Two Sample Assuming Unequal Variances

\begin{tabular}{|l|c|c|}
\hline & MV/BV > 1 & MV/BV <1 \\
\hline Observations & 31 & 3 \\
\hline Mean & 6.04 & 2.35 \\
\hline Variance & 18.65 & 1.14 \\
\hline t-value & \multicolumn{2}{|c|}{-3.72} \\
\hline t- critical value (one tail) & \multicolumn{2}{|c|}{1.80} \\
\hline p-value (one tail) & \multicolumn{2}{|c|}{0.002} \\
\hline
\end{tabular}

It can be seen that the average $R \& D$ expenditure in case of value creating companies is higher at 6.04 , whereas that of the other group is only 2.35 . This observation can have two inferences: (i) R\&D expenditure may emerge as an explanatory factor for the differences in MV/BV ratios, and (ii) that there is some threshold level of R\&D expenditure, below which it may prove to be only a wasteful exercise. This clears the issue raised while discussing the results of test of Hypothesis-2.

It emerges from the above analyses that MV/BV ratio gets explained by two factors: (i) ROE, which is a measure of current profitability for the shareholders, and (ii) R\&D Intensity, which contains a promise for the future profitability_ i.e. a promise for growth. Towards that, Hypothesis-7 calls for conducting regression analysis. As contemplated in the problem statement, the value creation is modeled as a function of current profitability and future profitability. Towards that, MV/BV ratio 
is chosen as dependent variable, while ROE and R\&D Intensity are identified as independent variables. The regression results are compiled in Tables 8(a) and 8(b).

Table 8(a) Simple Regression Result for Companies with $R \& D$ and $M V / B V$ Ratio $>1$

\begin{tabular}{|l|c|c|}
\hline Dependent Variable & Independent Variable & Independent Variable \\
\hline MV/BV Ratio & R\&D Intensity & ROE \\
\hline Beta Coefficient & 0.41 & 0.16 \\
\hline t-Statistic & 6.80 & 9.25 \\
\hline p-value & 0.000 & 0.000 \\
\hline R Square & 0.61 & 0.74 \\
\hline Adjusted R Square & 0.57 & 0.71 \\
\hline
\end{tabular}

Table 8(b) Simple Regression Result for Companies with R\&D and MV/BV Ratio $<1$

\begin{tabular}{|l|c|c|}
\hline Dependent Variable & Independent Variable & Independent Variable \\
\hline MV/BV Ratio & R\&D Intensity & ROE \\
\hline Beta Coefficient & 0.32 & 0.07 \\
\hline t-Statistic & 3.16 & 1.85 \\
\hline p-value & 0.09 & 0.21 \\
\hline R Square & 0.83 & 0.63 \\
\hline Adjusted R Square & 0.33 & 0.13 \\
\hline
\end{tabular}

It can be seen that in both the cases, MV/BV ratio gets explained by ROE and $R \& D$ Intensity, with $R \& D$ Intensity having more weightage. As shown in Table 8 (a), in case of the companies engaged in $R \& D$ and having MV/BV ratio greater than 1 , the beta coefficient for R\&D Intensity is 0.41 and for ROE it is 0.16 . The $R^{2}$ is 0.61 and 0.74, respectively. As can be seen from Table 8(b), in case of the companies engaged in $R \& D$ and having MV/BV ratio less than 1 , the $R^{2}$ for $R \& D$ Intensity being 0.83 is quite encouraging, but the beta coefficient for $R \& D$ Intensity is statistically insignificant. This brings to the fore the R\&D Intensity as the differentiator between the two sets of companies. When this result is interpreted in conjunction with the result of t-Test as shown in Table 7, it clearly implies that R\&D Intensity has to be above a threshold level; otherwise, it would prove to be wasteful expenditure. Put other way round, it means that only when R\&D Intensity is more than the threshold level, investors place a higher value as it has a promise for future. This is in line with the findings of Chan, Lakonishok and Sougiannis (2001) discussed in Section-2, above.

Further, the ROE, which is articulated as a measure of current profitability requires a proper interpretation in conjunction with the EBIT Margins. Since higher EBIT Margin for value creating companies comes from commanding premium price for the products, it gets influenced by the R\&D Intensity, too! This observation magnifies the effect of R\&D Intensity.

As far as ROA (which is a product of EBIT Margin and Asset Turnover Ratio) is concerned, it is observed that both of its constituents are higher in case of value creating companies. This gives a new insight that quality leadership has advantage in 
margin but does not have disadvantage in terms of decreased asset turnover ratio. This is a typical of pharmaceutical industry (in contrast to the generalized DuPont identity) because though the quality leadership is created out of R\&D and the entire R\&D expenditure by and large is written off in the Profit \& Loss Account, the R\&D firms enjoy very high sales. Thus, the asset base does not increase, and the asset turnover ratio does not decrease. However, it is interesting to notice that $R \& D$ companies have the margins so high that after absorbing R\&D expenditure, the net margin percentage still turns out to be higher than non-R\&D companies. It means that brand commands a lot of value. The shareholders rightly look upon $R \& D$ as a promise for growth, and not as an expense.

\section{Conclusion}

We have studied 73 pharmaceutical companies in India for which all the required data were available for the period of 10 years period from 2005-06 to 2014-15. The entire sample was divided into three classes:(i) those indulging into R\&D and having $\mathrm{MV} / \mathrm{BV}$ ratio greater than 1 , (ii) those indulging into $\mathrm{R} \& \mathrm{D}$ and having $\mathrm{MV} / \mathrm{BV}$ ratio equal to or less than 1 , and (iii) those not indulging into R\&D with the ultimate aim of modeling their MV/BV ratios as a function of their ROE and R\&D Intensity. However, instead of directly running the regression, we have first opted for examining the righteousness of using those explanatory variables. Towards that, using the Du Pont framework, and the tools of ANOVA and t-Test, we have tested the theoretical relationships among the ROE, ROA, EBIT Margin, and Equity Multiplier in a stepwise manner. This route helped us gain good insights into the interrelatedness of those four variables. Particularly, it was revealed that those firms who invested in R\&D beyond a minimum threshold, ripped the benefits very well. Not only that they created a promise for the future profit out of it, but at the same time, they could charge premium price for their products resulting into elevation of the current profit, too. As opposed to the normal understanding, the current profit and the future profit are not mutually exclusive, rather, they can go hand in hand. Thus, the debate on the current profit versus future profit gets dismissed at least in case of the pharmaceutical industry in India. There is also another interesting observation which is contrary to the established Du Pont framework. It is commonly accepted that in a fully competitive market, both the quality leadership as well as cost leadership would result into only the normal profits. Of course, the quality leaders will have higher profit margins but lower turnovers, and vice-a-versa for the cost leaders. However, in reality, most of the industries have oligopolistic structures, and the pharmaceutical industry is no exception. (For example, see Browning and Zupan, 2002). Given that, this empirical study reveals that in an oligopolistic competition, a firm can have both the margins and the turnovers higher. Thus, a firm can create positive impact in the product market and the capital market through pursuing the R\&D extensively.

Finally, conducting a simple regression analysis, we find that both_the current profit and future profits_ explain market valuations of the firms. However, the R\&D Intensity, which stands as a promise for future profits, turns out as the most powerful factor in case of value creating companies. Nonetheless, it comes with a riddle that the R\&D Intensity must be above its threshold level.

Our research has conclusively found the shareholder reaction in pharmaceutical industry in favor of future profits, which casts its vote for value maximizing behavior 
on the part of decision-makers which is opposite to the profit maximizing behavior as hypothesized under 'short-termism' by Alfred Rappaport (2011). Rappaport lists out various dimensions of short-term orientation of investors as well as corporates, which essentially result into valuing immediate return (i.e. current profit) more over the future profit. He flags a high alert to such an unfortunate situation which he found even in matured markets like Europe and the US. However, so far as R\&D dimension is concerned, at least in case of the pharmaceutical industry, we can proudly declare that the corporates as well as the investors provide a clear evidence of maturity even in a developing economy like India. In fact, such a claim contains a lot more beyond the proud! Particularly, since the present capital market regulations are largely designed on the contrary premise of lower maturity level, evidences of higher levels of market maturity, if found across the board, would prove to be a game changer.

Before we close, we would like to make it clear that though our results are quite in line with the results obtained by many other scholars, they suffer from the limitation caused by relatively small sample size. This offers opportunity for conducting similar studies with larger sample size, may be cutting across the industries.

\section{References}

1. Branch, B., \& B. Gale, "Linking Corporate Stock Price Performance to Strategy Formulation," Journal of Business Strategy, 4(1), 1983, 40-50.

2. Browning, Edgar \& Zupan, Mark, Microeconomics: Theory \& Applications, 7th edition, 2002, John Wiley \& Sons.

3. Chan, L. K., J. Lakonishok, and T. Sougiannis, "The Stock Market Valuation of Research And Development Expenditures," The Journal of Finance, 56(6), 2001, 2431-2456.

4. Chan, S. H., J. D. Martin, and J. W. Kensinger, "Corporate Research And Development Expenditures And Share Value,” Journal of Financial Economics, 26(2), 1990, 255-276.

5. Chao, R. O., and Kavadias, "R\&D Intensity And The NPD Portfolio," Available at SSRN 1330154, 2009.

6. Chen, M. C., S. J. Cheng, and Y. Hwang, "An Empirical Investigation of The Relationship Between Intellectual Capital And Firms' Market Value And Financial Performance,” Journal of Intellectual Capital, 6(2), 2005, 159-176.

7. Chen, P. C., W.C. Chan, S. W. Hung, Y. J. Hsiang, and L.C. Wu, "Do R\&D Expenditures Matter More Than Those of Marketing to Company Performance?," Technology Analysis \& Strategic Management, 28(2), 2016, 205-216.

8. Cockburn, I. M., and Z. Griliches, "Industry Effects and Appropriability Measures in the Stock Markets Valuation of R\&D and Patents," NBER Working Paper Series, Working Paper No. 2465, 1987.

9. Doukas, J. and L. Switzer, "The Stock Market's Valuation of R\&D spending and market concentration," Journal of Economics and Business, 44(2), 1992, 95144.

10. Ehie, I. C., and K. Olibe, "The Effect of R\&D Investment on Firm Value: An Examination of US Manufacturing and Service Industries.” International Journal of Production Economics, 128(1), 2010, 127-135. 
11. Gu, L., "Product Market Competition, R\&D Investment, and Stock Returns." Journal of Financial Economics, 119(2), 2016, 441-455.

12. Lee, M., \& M. Choi, "Analysis on Time Lag Effect of Research and Development in the Pharmaceutical Industry in Korea." Osong Public Health and Research Perspectives, 6(4), 2015, 241-248.

13. Lev, B., \& T. Sougiannis, "Penetrating the Book-To-Market Black Box: The R\&D Effect," Journal of Business Finance \& Accounting, 26(3-4), 1999, 419449.

14. Lome, O., A.G. Heggeseth \& O. Moen, "The Effect of R\&D on Performance: Do R\&D Intensive Firms Handle a Financial Crisis Better?," The Journal of High Technology Management Research

15. Jaffe, A. B., "Technological Opportunity and Spillovers of R\&D: Evidence From Firms' Patents, Profits And Market Value," American Economic Review, 76, 1986, 984-1001

16. Rappaport, A., Saving Capitalism from Short-Termism. How to Build LongTerm Value and Take Back Our Financial Future, 2011, New York.

17. Sonenshine, R. M., "The Stock Market's Valuation of R\&D and Market Concentration in Horizontal Mergers," Review of Industrial Organization, 37(2), 2010, 119-140.

18. Sougiannis, T., "The Accounting Based Valuation of Corporate R\&D," Accounting Review, 1994, 44-68.

19. Szewczyk, S. H., G. P. Tsetsekos and Z. Zantout, "The Valuation Of Corporate R\&D Expenditures: Evidence From Investment Opportunities And Free Cash Flow," Financial Management, 1996, 105-110

\section{Web Links}

1. http://www.imanet.org/docs/defaultsource/thought_leadership/management_control_systems/measuring_and_mana ging_shareholder_value_creation.pdf?sfvrsn=2 (Retrieved Date: 02/05/2015)

2. http://www.mca.gov.in/Ministry/notification/pdf/AS_26.pdf (Retrieved Date: 04/05/2015)

\section{About Our Authors}

Deepak Danak is with Institute of Management, Nirma University, Ahmedabad, India as a Professor in Finance Area. His current research interests include shareholder value creation, stock market efficiency, and ethics.

Punita Rajpurohit is a doctoral student in Finance Area at Institute of Management, Nirma University, Ahmedabad, India. Her current research interests are financial reporting and shareholder value creation. 